(C) 1986 ISIJ

\title{
浮上式鉄道と使用材料
}

中島

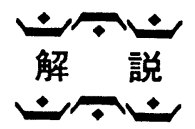

洋*

\section{The Materials on Magnetically Levitated High Speed Trains}

\section{Hirōshi Nakashima}

\section{1. はじめに}

高速で安全な大䝑輸送機関の最も有望な方式として, 国鉄では，この 10 数作来超電導磁不を用いた誘導反発 式磁気浮上式鉄道の開発をすすめてきている。その-... の実証の場として, 宮崎帠日问门に約 $7 \mathrm{~km}$ の些験線を 建設して，高速浮上走行の牛験を繰り返し行い，行々と 成果を上げていることはすでに知つて扣られる少も多い と思5.

この超電導磁不を利用した浮上式鉄道の最も大きな特

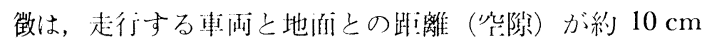
程度保持することができることと，推進に间じく趋长渞 磁石を利用した地上一次のリニアシンクロナスモータを 採用していることから, 従米の上らに車輪の摩擦に頼る

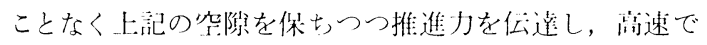
走行できることである，行つて，同じ仇道の不整条件 (理想的な軌道状態からのずれ) に対して,より高速で 安定して走行し得る可能性をを持つている.

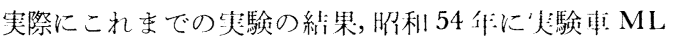

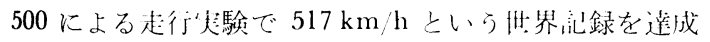

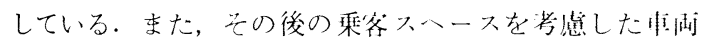
MLU 001 によつて, $400 \mathrm{~km} / \mathrm{h}$ の赴行を碓涊すると共 に約 $300 \mathrm{~km} / \mathrm{h}$ の速度で，住人徒を繰り返し行つてお り，各所の有識車に武乘していただき好誹を得ている。

このよらな浮上式鉄道で，もつとも特哞な技術分野

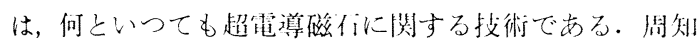
のように，超電導を維持するためには約 $4 \mathrm{~K}\left(-269^{\circ} \mathrm{C}\right)$ といら極低温度を保つことが必要条件となり，そのため の冷却が課題となる。この冷却を行らには, 液体一リり ムを使用する必要があるが，人リウムの资源上の問題拉 よび日本における価格の南から，将米システムにおいて 使用したへリウムを使い唅てにすることは泎されない。

従つて，国鉄における浮上式鉄道の開発においては， その当初から車上に搭載した冷凍機によつてへリウムを 外部に放出しないクローズドなシステムを構成すること を前提として進めてきている。
このために, 浮上式鉄道の開発には, 超電導磁石（超 笔導コイルおよび極低温容器）とこれを冷却するための 冷凍機执よびこの両者を含めた冷凍システムの構成方法 の三つが重要な開発課題となつている.

本文には，浮上式鉄道と使用材料といら命題をいただ いたが，ここでは浮上式鉄道全般の紹介と共に，材料面 では超電導技術関係に焦点を絞つて述べる。

\section{2. 浮上式鉄道の紹介}

\section{$2 \cdot 1$ 推進亡浮上の原理}

図 1 は, 宮崎奏験線における車両と軌道の断面構成を ホすす.浮上式鉄道は原理的には推進のためのリニアシン クロナスモータと浮上案内のための誘導反発及び誘導案 内の組命せで構成されている。

リニアシンクロナスモータは, 推進案内用の地上コイ ル群に地上電源（サイクロコンバータ）より，速度に応 じた周波数の 3 相電流を流すことによつて, 移動磁界を 発生:せしめ，この移動磁界に同期して超電導磁不が移動 し，絬果的に車両が走行するものである.

車雨の浮上は, 同じく浮上用の地上ニイル (常電導) 々の間の電気的な反発力で行われる. 推進案内用の地上 コイルと異なつた点は, 推進案内用が地上に配置された 琶源と接続されているのに対して, 浮上用は, それぞれ の地上コイルが個々に閉じたループであり，外部と一切 電気的に接続されていないことである. 車両が走行する

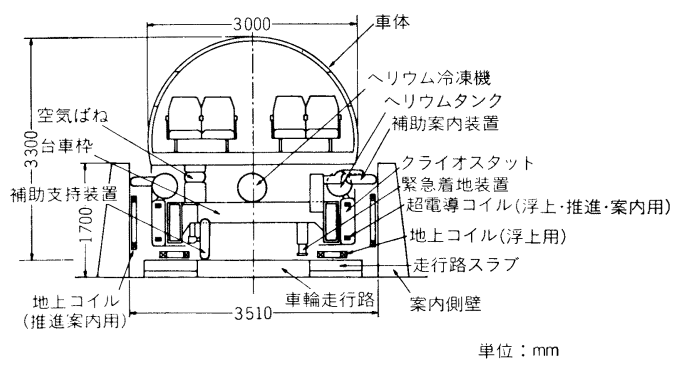

図 1 实験車 MLU 001 の断面構成

昭和 60 作 9 月 9 日受付 (Received Sep. 9，1985) (依頼解説)

* 鉄道技術研究所 (Railway Technical Research Institute, Japanese National Railways, 2-8-38 Hikari-cho Kokubunji 184) 
と, 浮上用の地上コイルの上を超電導コイルが通過し, そのとき地上ュイルに磁束が入り込むために，一時的に 電流が誘起され，この電流と車上の超電導コイルとの間 に反発力が発生し浮上力となる. 従つて, 浮上力は車両 が走行することによつて初めて発生するものであり，ち ようど飛行機の翼の特性に似ている.

車両の案内は, 浮上と同じ原理によつて行つているが 異なつている点は, 車両が軌道の真中を走行していると きは案内力を発生する必要がないことから, 車両が軌道 の中央からずれたときのみ，そのずれ量に比例して中央 に戻すような力が発生するように, 左右の推進案内用地 上コイルを電気的に接続をしていることである，車両が 中央にあるときは，案内用の電流がゼ口であることか ら，ヌルフラックス方式と呼ばれている。 この案内に用 いる地上コイルは，上記の推進用のリニアシンクロナス モータに使用する地上コイルと同一のものである.

写真 1 は現地に使用している車両（MLU 001 の三両 編成の状態）をまをた写真 2 は上飞説明した地上側のコ イルの取り付状状態を示す.

図 2 は, 二両編成状態における車両の側面図を示して いるが，図 1 と組み合わせて見ることにより，超電導磁 石の配置の様子がわかる. 図のように超電導コイルは縦 型酒置したレーストラック形状のコイルで, 推進案内 用の地上コイルと対向した位置に配している.

\section{$\mathbf{2 \cdot 2}$ 開発の経緯}

浮上式鉄道の開発は, 昭和 45 年に将来の鉄道のある

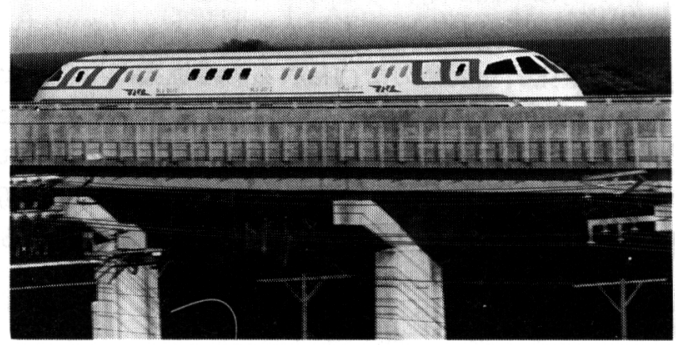

写真 1 MLU 001 の外観

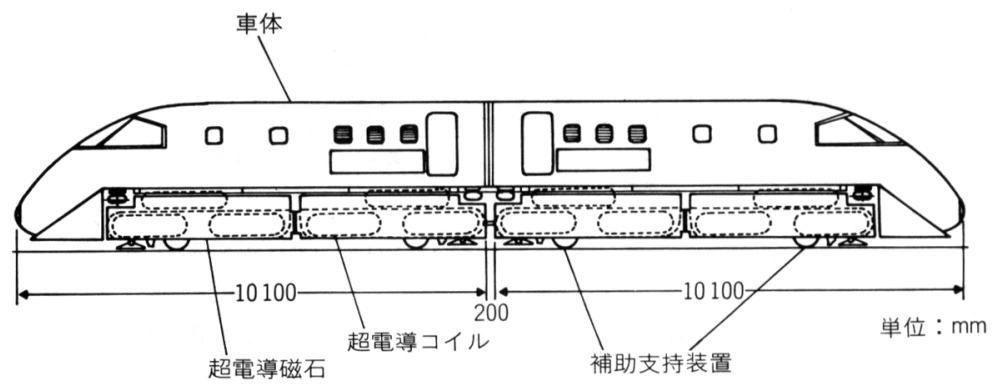

図 2 MLU 001 の測面図（2両 連結時)

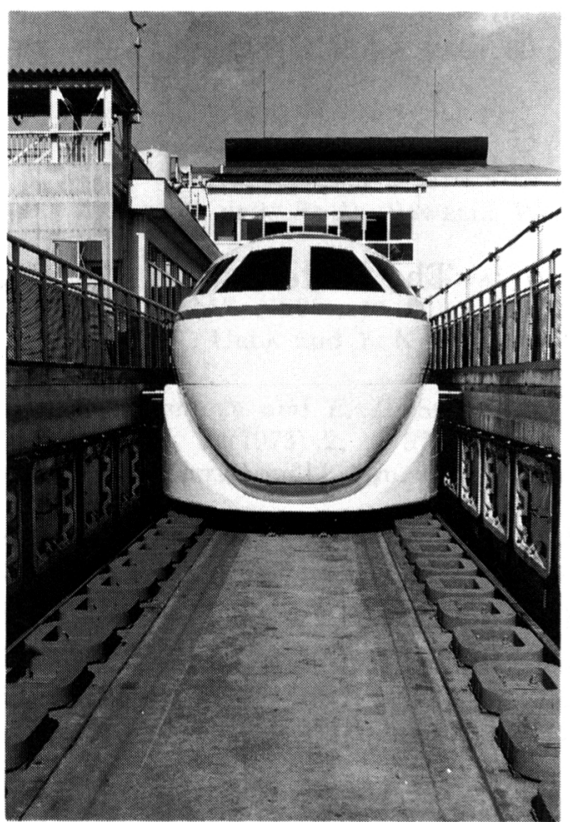

写真 2 地上コイルの。設置状況

べき姿として低公害性が重要な条件となるといら見通し のもとに, 昭和 41 年に米国のパウェル・ダンビィ両氏 が概念提案した方式を見直し，当時急速に発展しつつあ つた超電導磁石を用いた本方式の開発に着手することに なつたものである。

当初の研究は, 昭和 45 年の基礎試験装置から始ま り, 定置の超電導磁石を固定し, 浮上用の地上コイルを 円板上に乗せて回転せしめ，浮上力の確認を行つた，そ の後, 実際に実験車両を走行させて確認するシステムに 移行し, 昭和 47 年には, 国鉄 100 周年を記念して ML 100 による走行実験を行つた。これらの成果をもとに昭 和 52 年 4 月に, 高速走行実験による実証の場を宮崎県 日向市の実験センターに移行した.

その後の主な経過としては，昭和 54 年 12 月に 517 $\mathrm{km} / \mathrm{h}$ の世界記録を達成し，続いて上記の MLU 001 形の有人を考慮した車両に変更して実験をすすめてお り, これまでに 3 万 $\mathrm{km}$ 以上の走行を記録している. 
こらした開発にあわせて, 超電導磁石を冷却するため の車載用冷凍機の開発も精力的に進めてきた. 開発当初 は車上に搭載する冷凍機の可能性を疑問視する声もあつ たが，最近では実験車において繰り返し実証できる段階 になつている.

\section{$2 \cdot 3$ 実験車両}

実験車両は，図 2 に示してあるが，現設備の全車両を 連結すると 3 両編成での走行が可能となつている． 3 両 を連結した状態では全長が約 $30 \mathrm{~m}$ であり，各車両の幅 は $3 \mathrm{~m}$, 高さは $3.3 \mathrm{~m}$ で流線形をした軽量のアルミニ ウム命金製の車両である．車雨は，人が乗つて乗心地な ど各種の調䍒をできるように内部には座席が設けてあ る. 3 両の中の両端の車両には, それぞれ 8 席, 中間車 には 16 席，全体命計では 32 黁の座席を取りつけた構 成としている.

超電導磁不は台車枠と呼ばれる枠組みの上に取り付け られており，台車枠之車体とは空気ば权で結ばれてい る. また誘導反発形であるために，低速度の時にはごム タイヤによつて車体を支持する構造としており，上下支 持用と左：右案内用車輪とが設けられている. 停止および 低速度時にはこの車輪を油压によつて押し出しており， 高速度時には引き込める構造である。

超電導磁不については，次に詳細に説明するが，各車 両に 8 個の超電導コイルを搭載しており，この8 個の二 イルでもつて，約 $10 \mathrm{t}$ の車両を支えることになる．計 測用の浮上高さ計なども非接触で測定するために，高速 走行時には，地上側と接触するものは全くない構造とな つている.

つぎに，超電導磁不および令凍機などについて，その 概要を紹介するとともに，使用している材料について紹 介する.

\section{3. 超電導磁石}

浮上式鉄道の最も重要な設備の一つである超電導磁们 は, 超電導コイルとこれを低温に冷却するための極低温 容器（クライオスタット）とから棈成される.

実験車 MLU 001 に搭載している超電導磁石の概念 困を図 3 に示す。四に示すように，一部に二つの超電導

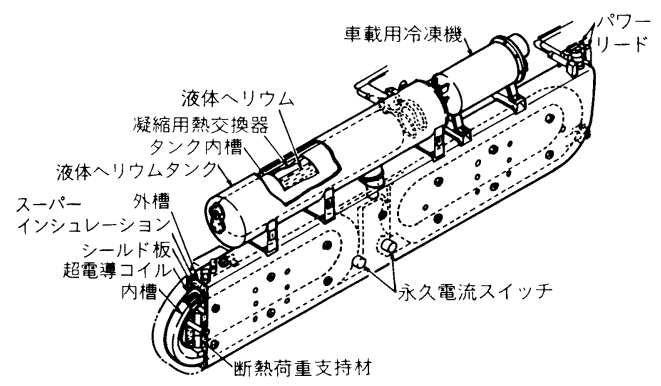

図 3 超電導磁石概念図
コイルを配置し，上部に液体ヘリウムタンクを配置して いる. 超電導コイルは, 内槽と呼ぶ筒型の容器内に収納 されて抢り，この内槽と超電導コイルの周りの空間に液 体へリウムが供給される構造となつている. また, 図中 右側に示す位置に冷凍機が取り付けられており，この冷 凍機によつて内部のへリウムガスが液化され, 封じ切つ た状態でヘリウムガスを外部に放出することなく運用で きるようになつている。

以下にそれぞれの要素について材料面からの問題点な どを中心に述べる.

\section{$3 \cdot 1$ 超電導コイル}

使用している超電導コイルの代表的な例の諸元を表 1 に示す. 表に示すように, 起磁力は $700 \mathrm{kA}$ (電流值 700 $\mathrm{A} \times 1000$ ターン) と非常に強力な磁石で, コイル部断 面での平均電流密度は $183 \mathrm{~A} / \mathrm{mm}^{2}$ とかなり高い值を確 保している.

使用している超電導線材は最も一般的な NbTi によ る線材で, ファインマルチのッイスト線で, 銅比（線材 の銅/ $\mathrm{NbTi}$ 重量配分比) が2のものを採用している. 最近では銅比が約 1 のものが開発の対象となつている.

超電導コイルは, レーストラック形状に巻線処理をし たのりに，真空含浸法によつてェポキシ系の樹脂を含浸 させ固めたもので，一度型枠から外した後に補強を加え てから内槽をその周辺に溶接により組み上げて製作して いる．補強材および内槽は，磁界の影響を避けることと 低温容器としての使用材料に関する法的制約からステン レス鋼 SUS 304L を全面的に採用している.

\section{$3 \cdot 2$ 断熱荷重支持材}

浮上式鉄道の車体を浮上・案内むたは推進させるため の力はすべて電磁気的なものであり, 上記の超電導コイ ルに加わることになる，従つて，台枠または車体にこの 力を伝達することが必要となる. ただし，超電導コイル との間には約 $300 \mathrm{~K}$ の温度差があり，これらの間の断 熱方法は重要な課題となる. そのため, この力を伝達す るための断熱荷重支持材はクライオスタットの設計上重 要な役割を有する. 断熱荷重支持材に使用する材料と構 造が，その性能を大きく左右することになり，当然のこ ととして強度が大きく熱伝導率が小さい材料が望まれる ことになる.図 4 はこの断熱荷重支持方式として採用さ れている一つの例であるが，構造的には限られた空間内 で伝熱距離を大きくとれるよらに工夫したものである. 図に示す例は，直径の異なる複数の円筒を同心円状に配

表 1 超電導コイルの代表例

\begin{tabular}{|c|c|c|}
\hline 項 & 諸 元 & 備 \\
\hline 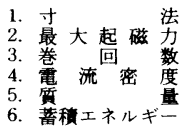 & $\begin{array}{l}1700 \times 500 \mathrm{~mm} \\
700 \mathrm{kA} \\
1000 \mathrm{~g}-\dot{-} \\
183 \mathrm{~A} / \mathrm{mm}^{2} \\
97 \mathrm{~kg} \\
532 \mathrm{~kJ}\end{array}$ & レーストラック型 \\
\hline
\end{tabular}




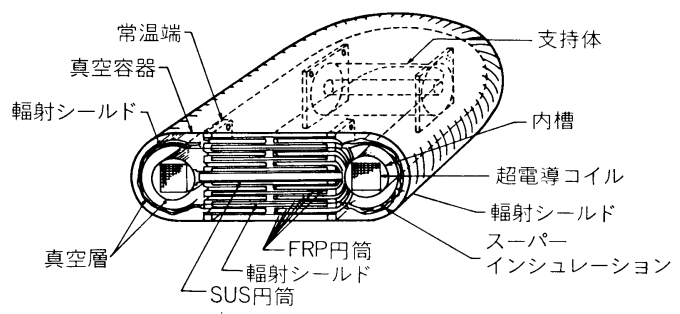

図4 断熱荷重支持方式の例

置し，隣り合う円筒の端部同士および中央部同士を交互 飞結合したものであり, 最も内側の円筒を超電導コイル の内槽に, 外側の円筒を外槽に接続することによつてあ らゆる方向の力を支持できる構造としたものである.

このような断熱荷重支持材に使用している材料は, 現 在ではほとんどすべてが繊維強化プラスチック (FRP) である. 各種の材料について熱伝導泫と強度の特性の比 を比較すると FRP は優れた特性を有しており，金属で はステンレス鋼の特性が優れている。そのために共に断 熱荷重支持材として従来から良く使用されているが，前 者の方が特性的には勝つており最近では车績が積まれる につれて定着してきている．また共に低温になるほど熱 伝導率が低下するといら歓迎すべき特性を有している。

採用しているFRP としては, ガラス繊維強化デラス チック (GFRP) と炭素繊維強化プラスチック (CFRP) が対象となつている。これは, 低温領域において CFRP の方が熱伝導率が小さくなるためで, 液体空素温度以上 をGFRP，以下をCFRP といら使いわけをしばしば行 つている.

\section{$3 \cdot 3$ パワーリード}

浮上式鉄道に使用寸る超電導磁石は, 走行時はいわゆ る永久電流状態にて使用している. 磁石を励磁するには 地上に設置した励磁電源に磁石のパワーリードを接繶 乙, 励磁したのちに内部の永久電流スイッチを閉じる. この後は励磁電源とは全く縁を切ることになる.このハ ワーリードは超電導磁石の設計上, 熱侵入の大小を大き く左右する要素である.

現在使用しているパワーリードは，通電時に発生した ガスヘリウムをパワーリードの導体の冷却に使用し, 発 熱によつて温度が過剩に上昇しないように設計してい る.
このパワーリードに使用する材料の選択と構造の洪め 方が禹要な事柄となり，材料面では電気抵抗が小さく， から熱伝渞摔の低いことが要求されるが，この条件にぴ つたり介材料は無いのが現状であり, 类際の設備では りえ脱酸銅などを採用している．現在超電導磁石の熱侵 入約 $2 \mathrm{~W}$ の中に占めるパワーリードによる熱侵入の割 合は磁不によつて異なるが拈拈を衫2 3 制程度となつ ている.

\section{4 その他}

超電導磁不は，内槽と外槽の閏を高度の真空に保つ必 要があり，そのために使用する忉料子強度が十分で気密 性が高いものであること, 組汒時の溶接性が優れている ことなどが必要条件となる。こうした点からも内槽には 尃らステンレス鋼 SUS 304L が採用されるが，外槽は 外部から大気压をらける外压畒器となり, 内側に補強を 入れにくいこともあり，撓みを少なくする対策から比軹 的㨻い材料を用いることが多く, 従つて, 材料もアルミ ニウムを採用することが多い。

また，浮上式鉄道では磁界変化の内槽への影響を少な くする川的で, 外槽には電気抵抗の小さい忉料を使用す

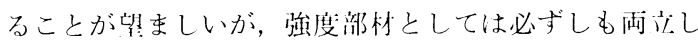
ないために现人には構造材料としてはA 5083 アルミニ ウム介金を使用し，さらに外側に A 1100 などの純了ル ミニウムを事权るような構成としている。

また, 内槽と外槽の間は, 種々の配管で結合されてい るが，中間でアルミニウムとステンレス鋼を真空気密を 保七つつ接付することになり，特殊なジャンクションを 必要としている. 具休的には常温側においてアルミニウ ムとステンレス鋼の摩摖压接によるジャンクションを使 用し，それぞれを浴接で接令している。

\section{4. 車載用冷凍機}

浮上式鉄道車両の車上に搭载する車載冷谏システムの 構成は, 開発の中心的課題であつたために东駼車両にお いても種々の構成力法を比較調查している. 図 5 は央験 車両 MLU 001 の 3 雨分の冷谏システムの構成を示し たものである。

冷涷機内で発生したミスト（液体へリウムとガスへリ ウムの混介状態で $4.3 \sim 4.4 \mathrm{~K}$ 程度の温度) は磁石内の 凝縮用の熱交換器に送り込まれ, 磁不内のガスーリウム はこの凝縮用熱交換器の外部で㠜縮液化する。磁不の熱

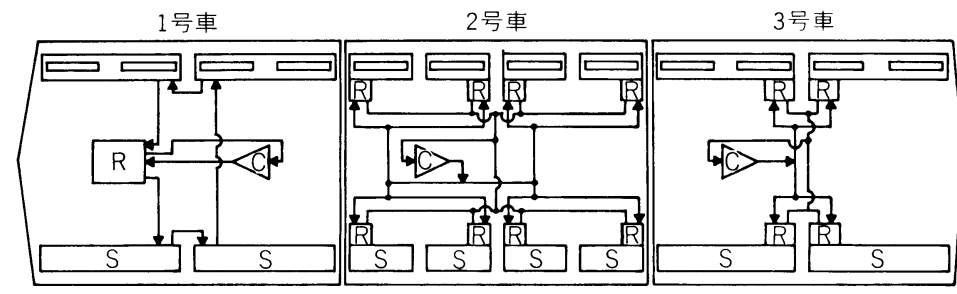

$\mathrm{S}$ : 超電導磁石 C：压綰機 $\mathrm{R}$ ：冷凍機

四 5 MLU 001 の車载冷凍機器の 配置 


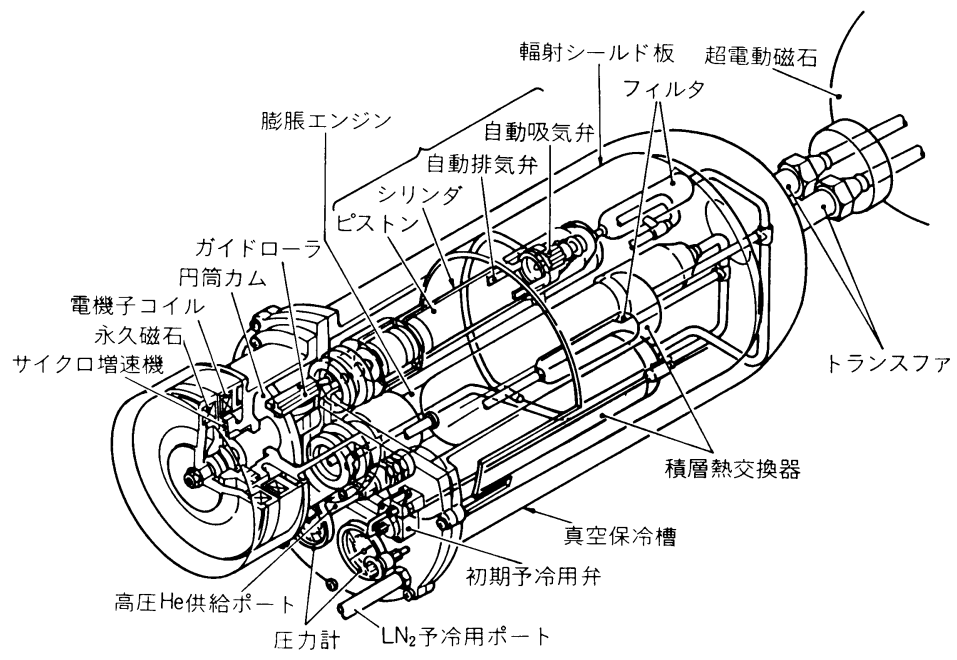

図 6 車載用冷凍機概念困

侵入量が多いと内槽内のへリウムの圧力が上昇し, 凝縮 用熱交換器で凝縮するへリウム量が多くなり, 結果的に 磁石の熱侵入とバランスした压力で一定に保たれること になる。

磁不々冷凍機の配置組合せ力には種々の構成方法があ る. 当初は車上に 1 台の冷凍機を配置し, 低温配管によ つて複数の磁石を冷却する方式（１品車）から試行をは じめたが，現在では磁石ごとに小型の冷凍機を分散する 万式 (2.3 号車) が定着してきている.さらにこの考え 方が進み冷凍機を磁石の外槽内に組み込むことによつて 一層の軽量化をはかる力向に進んでいる.

図 6 は，MLU 001 の 3 号車に搭載した冷涷機の概略 の構成を示す. 本冷凍機は, クロードサイクル冷凍機で あるが，このほかにスターリングサイクル冷凍機をも一 部に搭載して試験を行つている。

冷凍機は, 主な要素として熱交換器と膨脹エンジンが あげられる.それぞれが細かい分野において特殊な材料 を必要とするものであり，次にその概要を説明する.

\section{$4 \cdot 1$ 熱交換器}

現在クロードサイクル冷凍機の内部に使用している 熱交換器は, 新たに開発した積層板型の 熱交換器であ り, その構成を図 7 に示す. 積層板型の熱交換器の特徵 は, 対向流形のガスの流れに直角方向に金属の伝熱板之 FRP のスペーサを交互に多数配し, 両者を流路間の気 密を保もつつ接着材で接着したものである.

伝熱板としては, 熱伝導率が良く軽量なアルミニウム を使用し，スペーサとしては熱伝導率の悪いFRPを使 用し，かつ接着断面積をできる限り少なくするよらに努 力している. 両者の接着材は, 低温でも耐えられるよう なエポキシ系のものを使用している. もしも単一の材料 で熱伝導に著しい力向性を有するものがあれば，こうし た複雑な構成に頼らなくてもすむことになる。

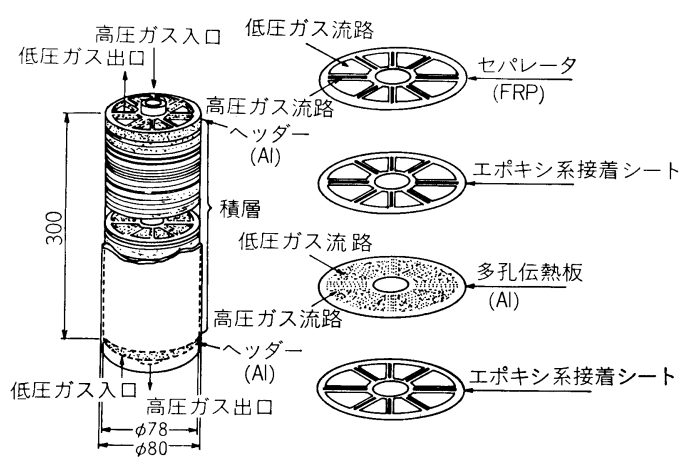

図 7 積層板形熱交換器の構成

なお，最近の冷凍機ではこらした熱交換器の内部に次 に述べる膨脹エンジンを組み达み, 全体の容積効率を高 くする努力を払つている.

\section{$4 \cdot 2$ 膨脹エンジン}

膨脹エンジンは, 高圧のガスに膨脹仕事を行わしめ, 低圧で低温のガスを発生させるための最も重要な機構部 で，冷凍機の低温領域では唯一の可動部となる．車載用 に開発した膨脹エンジンの特徵は, 小型化を図るため に, 吸入・排気のタイミングをすべてピストンの動きに よつて自動的に行ら特殊な弁を開発していることであ る.これらの機構部は特に低温部において油などの潤滑 材が一切使用できないことが設計上の悩又となり，その ため主としてテフロン系の材料によつて摺動部の発熱を 押さえている. 弁の座に用いるシール材も同様である.

膨脹部のシリンダーは磁石と同様にステンレス鋼 SUS 304L が主流であり，ピストンには熱伝導によるロスを 少なくするために主にベークライトなどが用いられる.

\section{$\mathbf{4 . 3}$ その他}

冷凍機としてこの他にスターリングサイクル冷凍機を 
搭載しているが，この冷凍機では蓄冷器を使用してい る.この蓄冷器に要求される基本的な特性として低温に おける熱容量が大きいことが挙げられる。そのために $20 \mathrm{~K}$ 程度を対象とする蓄冷器では鉛の小球を用いる. 他の材料の中では鉛の比熱が低温において比較的大きい ためであるが，それでも $10 \mathrm{~K}$ 近くになると十分でなく なり，一般にスターリングサイクル冷凍機では $15 \mathrm{~K}$ 以 下の冷凍はジュール・トムソンループを使用することに なる。

より特殊な例として，現在国鉄では科学技術广の振興 調整費を受けて, 直接 $4 \mathrm{~K}$ 冷却が可能なスターリング サイクル冷凍機の開発を行つている.この場命には, 上 記の条件により適した材料として GdEr, GdErRh など の希土類元素による化合物を用いている.これはこれら の材料が $20 \mathrm{~K}$ 以下に打いて比熱が大きくなる特異点を 持つていることを有効に利用しよらとするものである. これまでに $4 \mathrm{~K}$ レベルの冷凍が可能なことを头証して きており, 今後冷凍機としてまとめる予定である.

\section{5. その他 設 備}

以上，主に超電導とその冷却について焦点を絞つて記 してきたが，その他に浮上式鉄道の車両と軌道の面から 材料について紹介しておく.

\section{$\mathbf{5 \cdot 1}$ 車体関係}

車体に要求されることは，まず第 1 に軽量であること と十分な強度を有することである。この課題はほとんど すべての場合に必要な条件であり，基本的には航空機の 機体に対する要求と同じである，従つて，前記の台枠お よび車体はアルミニウム合金が主体である，浮上式鉄道 の場合には，強磁性体は好ましくないといら条件が加わ るが，軽量構造の車体を作る上からの制約とはなつてい ない.

また，複合材料も魅力ある材料であり，、ニカムや CFRP による構造材料は車体の各所に使用されている.

\section{$5 \cdot 2$ 軌道関係}

前述のように軌道は，鉄筋コンクリートで構成された 高架上に地上コイルを並べた構成となつている.このコ イルは主としてアルミニウム合金による線材をモールド 材 (SMC) で固めたものであり，耐候性の高いことが重 要な課題となつている. また推進案内用の地上コイルで は，耐絶縁特性の高いことが特に要求される。

軌道に関連して特殊な条件として，鉄筋または使用す
るボルトなどの材料には非磁性または磁性の弱いことが 望まれる。従米の強磁性体に代わり得る材料として高マ ンガン鋼が試験的に使用され，よい結果を得ている.

\section{6. おわりに}

浮上式鉄道の紹介とともに使用している材料面につい て解した．特に，本鉄道の最も特徽的な設備である低温 関係の内容を中心として紹介してきたが，必ずしも現在 使用している材料で満赼できているわけではなく，たと えば，電気伝導度と熱伝導度のように日由に特性の選扒 組命せができないために，悩及つつ折贵案としてまとめ ている場命が多い，従つて，多くの部分で新しい材料の 出現によつて設㖕方法と性能が大幅に改善されることが 十分に考えられ，材料面での新しい情報に期待するとこ ろは大きい。

今後とも，浮上式鉄道の開発にいいそうの御支援をい ただければ幸いであります。

\section{交献}

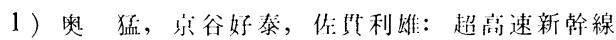
(1971)，［中公新菖］

2) J.R. Powell and G.R. Danby: ASME Paper 66-WA/RR-5 (1966)

3 ) 宗谷好泰：科学の起駗, 30 (1979) 7, p. 25

4 ) 等谷好泰：1本機械学会誌，84 (1981) 746, p. 12

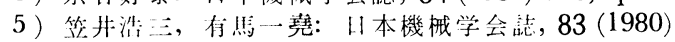
742 , p. 1121

6 ）林中寿：鉄道技術研究资料，37（1980） 5, p. 196

7 ）桨花武楌, 藤本健：鉄研報告，1171 (1981), p. 153

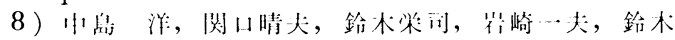
南男，下来年樹：鉄研報告，1171 (1981)，p. 194

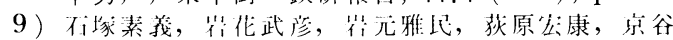

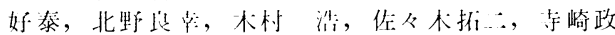

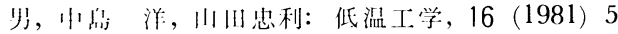

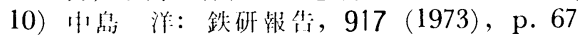

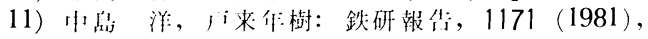
p. 173

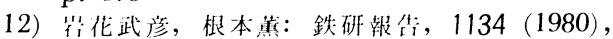
p. 103

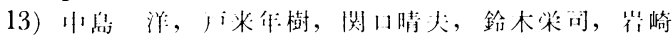
一头：鉄研㣮售，1134 (1980), p. 120

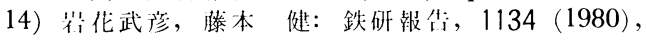
p. 92

15) 京行好夲：機械の研究，3 (1982), p. 34

16) Y. KYotani: Rail International, 4(1981), p. 155

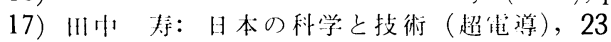
(1982) 216，p. 44 [科学技術餂] 